\title{
Assesement of Future Primary School Teachers' Educational Results
}

\author{
Olga G. Smolyaninova and Vera V. Korshunova* \\ Siberian Federal University \\ 79 Svobodny, Krasnoyarsk, 660041, Russia
}

Received 07.07.2015, received in revised form 21.07.2015, accepted 19.08.2015

Changes in training and assessment programmes of educational results of the future primary school teachers in the context of pedagogical education modernization, connected with the requirements of the professional teachers' standard are discussed in the research paper. In order to enhance practical orientation of the future primary school teachers training, the authors propose a technology for educational results assessment by the means of an electronic portfolio under conditions of networking of the major systems included in the training process: secondary vocational education system, higher education system and employers. Analyzing teachers' professional standard, job activities actions were identified for each of the job function (training, education and development), the delta at the higher education levels is defined (bachelors' degree) and levels of educational results assessment are proposed.

Keywords: integration; life-long pedagogical education; practice-orientated training, assessment technology, educational results, portfolio.

The research was carried out within project № 05.043.12.0031 initiated by the Ministry of Education and Science of Russian Federation.

DOI: 10.17516/1997-1370-2015-8-11-2645-2653.

Research area: pedagogy, psychology.

Modern education is moving to a higher technological level. A search for new pedagogical technologies is taking place, what is connected with the abandonment of the traditional approach in the future teachers training (Bolotov, 2014).

The trend of pedagogical education modernization is academic mobility, strengthening the practical orientation of training, search for the new assessment approaches in accordance with the teachers' professional standard.
According to the new generation standards, learning process is practice-oriented, aimed at the professional activities formation for their further use in the future teacher's professional environment: training, education and development of the primary school students. Training teachers' educational activity formation requires a significantly different model of practical training. The model of practice-oriented teachers' training introduction involves partnership of schools and universities (Guruzhapov, 2014).

(C) Siberian Federal University. All rights reserved

* Corresponding author E-mail address: smololga@mail.ru 
Educational technologies change as well, transition to the activity approach is taking place, interactive technologies and e-learning are used.

Within the model of future primary school teachers' practice-oriented training, an attempt to change the approach of professional training for bachelors, focus towards practical training increase and changing the system of educational results assessment has been made. Thus, the future primary school teachers' training is understood by the authors as a purposeful process of educational results formation through activity. Student's activity during the practical training is taking place according to a specific scheme, such as:

- participant observation of the professional activities samples;

- professional tests and their reflection during pedagogical practices distribution;

- independent professional activity (demonstration of the formed job activities) (pedagogical internship).

The novelty of the educational program for teachers' training is its modularity. Successful module learning is understood as simultaneous mastering of the theoretical, practical and research competencies that are obligatory within the frames of the professional tasks solution for each module of the educational programme. Module content is developed through theoretical training. Students' motivation to pedagogical activity is formed on the basis of organizationalactivity game (OAG). OAG is also the basis for the "start" of students' teaching practice, which begins from the first term and continues throughout the training period. The practice is an important part of training, as, it is there, where the precedent of the first experience, formation of the students' ability to solve professional problems, apply knowledge from the modules' subjects under supervisor's guidance, secondary vocational education facilitator and the practice curator from the university takes place (Margolis \& Rubtsov, 2010a, b).

At the end of each module, a student reaches certain educational results that are planned at the stage of the module's development and the whole basic professional educational programme (BPEP) design in general (Table 1). Educational results of the future primary school teachers in the practice-oriented training model are coordinated in the course of a dialogue between an employer (as the educational result customer) and a higher educational institution (as the educational result provider). At that, educational technologies are regarded as a way of professional competences formation in accordance with the professional teachers' standard, and evaluation tools as a way of involving independent professional assessment of the level of competences formation. Educational results of Bachelor's degree BPEP of "Primary School Teacher" profile, described in accordance with the professional teachers' standard, are given in Table 1.

As a result of discussions on competences in the professional community, formed in BPEP for Bachelor's degree, $82.5 \%$ of the total amount, described in the professional teacher's standard, was accentuated (Table 2). Distribution of the planned competence in accordance with professional standards in relation to the teacher essential job functions: training, education and development are represented in Table 2.

Assessment of the level of competence formation is a new challenge for the university system, which can not be solved only with the help of traditional methods of control and assessment tools. In addition, generally accepted methodological tools for the formation and use of assessment tools funds for the professional competences assessment are not formed at the moment. Every higher educational institution solves this problem independently. Competencies 
Table 1. BPEP Educational Results

\begin{tabular}{|c|c|}
\hline BPEP module & Professional competences of the teacher's professional standard \\
\hline $\begin{array}{l}\text { Module } 1 . \\
\text { Subjects of } \\
\text { humanitarian } \\
\text { and economic } \\
\text { cycle }\end{array}$ & $\begin{array}{l}\text { 1) 6.1O Ready for the implementation of academic disciplines programmes within the } \\
\text { frames of the basic general education programme } \\
\text { 3) 6.10 Ready for taking part in implementation of educational organization development } \\
\text { programme in order to create safe and comfortable education environment } \\
\text { 14) 6.1O Ready for defining and establishing clear regulations for students in accordance } \\
\text { with educational organization regulations and internal rules of conduct of the educational } \\
\text { organization } \\
\text { 20) 6.1O Ready to develop students' cognitive activity, independence, initiative, creativity, } \\
\text { social position formation, ability to work and live in the modern world, formation of } \\
\text { students' culture of healthy and safe lifestyle } \\
\text { 21) 6.1O Capable of tolerance and behavioral skills development in the changing } \\
\text { multicultural environment }\end{array}$ \\
\hline \begin{tabular}{|l} 
Module 2. \\
Subjects of \\
mathematical \\
and natural \\
scientific cycle
\end{tabular} & $\begin{array}{l}\text { 6) 6.1O Ready for the implementation of educational achievements monitoring and } \\
\text { assessment, current and final results of the basic educational programme mastering by } \\
\text { students } \\
\text { 8) 6.1O Ready for the development of skills related to information and communication } \\
\text { technologies (hereinafter - ICT) } \\
\text { 11) 6.1O Ready to regulate students' behavior to ensure safe educational environment } \\
\text { 20) 6.1O Ready to develop students' cognitive activity, independence, initiative, creativity, } \\
\text { social position formation, ability to work and live in the modern world, formation of } \\
\text { students' culture of healthy and safe lifestyle }\end{array}$ \\
\hline $\begin{array}{l}\text { Module } 3 . \\
\text { Theoretical } \\
\text { and } \\
\text { experimental } \\
\text { foundations of } \\
\text { psychological } \\
\text { and } \\
\text { educational } \\
\text { activity }\end{array}$ & $\begin{array}{l}\text { 2) 6.1O Ready to carry out professional activity in accordance with the requirements of } \\
\text { the federal state educational standards for preschool, primary general, basic general and } \\
\text { secondary education } \\
\text { 13) } 6.10 \text { Capable of setting educational goals that contribute to students' development, } \\
\text { regardless of their abilities and character } \\
\text { 5) 6.1O Ready for the systematic analysis of the training sessions effectiveness } \\
\text { 16) } 6.10 \text { Ready to implement educational opportunities of the various types of children } \\
\text { activities (educational, game, work, sports, artistic, etc.) } \\
\text { 25) 6.1O Ready to use tools and methods of diagnostics and assessment of the indicators of } \\
\text { children's level and development dynamics }\end{array}$ \\
\hline $\begin{array}{l}\text { Module } 4 . \\
\text { Phycology and } \\
\text { pedagogics } \\
\text { of child } \\
\text { development }\end{array}$ & $\begin{array}{l}\text { 1) 6.1O Ready for the implementation of academic disciplines programmes within the } \\
\text { frames of the basic general education programme } \\
\text { 4) 6.1O Ready for the training sessions planning and giving } \\
\text { 5) 6.1O Ready for the systematic analysis of the training sessions effectiveness } \\
\text { 6) 6.1O Ready for the implementation of monitoring and assessment of educational } \\
\text { achievements, current and final results of the basic educational programme mastering by } \\
\text { students } \\
\text { 9) 6.1O Ready for formation of the motivation to learn } \\
\text { 10) 6.1O Capable of objective assessment of students' knowledge on the basis of testing and } \\
\text { other methods of control in accordance with the real educational opportunities of children } \\
\text { 23) 6.1O Ready to identify behavioral and personal students' problems, related to their } \\
\text { development peculiarities, in the course of observation } \\
\text { 26) 6.1O Capable of mastering psychological and pedagogical technologies (including } \\
\text { inclusive) needed for targeted work with different groups of students: gifted children, } \\
\text { vulnerable children and children in difficult life situations, migrant children, orphans, } \\
\text { children with special educational needs (autism, children with attention deficit and } \\
\text { hyperactivity, etc.), children with disabilities, children with behavioral deviations and } \\
\text { children with addictions } \\
\text { 27) 6.1O Ready to provide targeted assistance to students } \\
\text { 37) 6.1C Capable of objective assessment of students' success and possibilities, taking } \\
\text { into account individual mental development of primary school age children, as well as } \\
\text { peculiarities of the training activity development dynamics for boys and girls }\end{array}$ \\
\hline
\end{tabular}


Continuation Table 1

\begin{tabular}{|c|c|}
\hline $\begin{array}{l}\text { Module } 5 . \\
\text { Methodology } \\
\text { and } \\
\text { techniques of } \\
\text { psychological } \\
\text { and } \\
\text { educational } \\
\text { activity }\end{array}$ & $\begin{array}{l}\text { 1) 6.1O Ready for academic disciplines programmes implementation within the frames of } \\
\text { the basic general education programme } \\
\text { 5) 6.1O Ready for the systematic analysis of the training sessions effectiveness } \\
\text { 6) } 6.10 \text { Ready for the implementation of monitoring and assessment of educational } \\
\text { achievements, current and final results of the basic educational programme mastering by } \\
\text { students } \\
\text { 7) 6.1O Ready for the universal educational actions formation } \\
\text { 19) 6.1O Capable of maintaining order, atmosphere and traditions of the educational } \\
\text { organization } \\
\text { 26) 6.1O Capable of mastering psychological and pedagogical technologies (including } \\
\text { inclusive) needed for targeted work with different groups of students: gifted children, } \\
\text { vulnerable children and children in difficult life situations, migrant children, orphans, } \\
\text { children with special educational needs (autism, children with attention deficit and } \\
\text { hyperactivity, etc.), children with disabilities, children with behavioral deviations and } \\
\text { children with addictions } \\
\text { 27) 6.1O Ready to provide targeted assistance to students } \\
\text { 39) 6.1C Ready for educational activity correction, based of the educational results } \\
\text { monitoring data, taking into account uneven individual mental development of primary } \\
\text { school age children (including those due to differences in age, pre-school education and } \\
\text { upbringing conditions), as well as peculiarities of development dynamics for boys and girls }\end{array}$ \\
\hline $\begin{array}{l}\text { Module } 6 \\
\text { Educational } \\
\text { activity } \\
\text { and social } \\
\text { pedagogy } \\
\text { in primary } \\
\text { education }\end{array}$ & $\begin{array}{l}\text { 2) 6.1O Ready to carry out professional activity in accordance with the requirements of } \\
\text { the federal state educational standards for preschool, primary general, basic general and } \\
\text { secondary education } \\
\text { 12) 6.1O Ready for the implementation of modern, including interactive forms and methods } \\
\text { of educational work, using them both in class and in extracurricular activity } \\
\text { 13) 6.1O Capable of setting educational goals, contributing to the students development, } \\
\text { regardless of their abilities and character } \\
\text { 15) 6.1O Ready for educational programmes implementation } \\
\text { 17) 6.1O Capable of designing the situations and events that develop emotional and value } \\
\text { sphere of children (emotional culture and values of a child) } \\
\text { 18) 6.1O Capable to help and support in organizing students' self-government bodies } \\
\text { activity } \\
\text { 22) 6.1O Capable to use constructive educational efforts of students' parents (legal } \\
\text { representatives) and assist to families in the issues of child rearing } \\
\text { 29) 6.1O Capable, in association with parents (legal representatives), to implement } \\
\text { individual child development programmes } \\
\text { 33) 6.1O Capable to establish a system of behavior and students' activity regulation } \\
\text { 35) 6.1C Capable to form students' social position throughout the whole period of studying } \\
\text { at primary school } \\
\text { 36) 6.1C Ready for the metasubject competences, the ability to learn and universal } \\
\text { educational actions formation up to the level required for mastering educational programmes } \\
\text { of the basic general education } \\
\text { 38) 6.1C Ready for the educational process organization taking into account the } \\
\text { peculiarities of the social situation of the first-form student }\end{array}$ \\
\hline
\end{tabular}

assessment is an integral part of the educational system and accomplishes the function of control over the educational results achievement - the level of competences formation in the process of BPEP mastering.

Within the model of practice-oriented training of the future primary school teachers under conditions of educational institutions of higher and secondary vocational education networking, the IEPS SFU project team understands educational results as student's readiness and ability to demonstrate practical effect of the professional teacher's functions in accordance with professional teacher's standards, 
Table 2. Proportion of the professional standard's job activities of job functions

\begin{tabular}{|l|c|c|c|c|c|}
\hline $\begin{array}{c}\text { Job functions } \\
\text { (JF) }\end{array}$ & Training & $\begin{array}{c}\text { Educational } \\
\text { activity }\end{array}$ & $\begin{array}{c}\text { Developmental } \\
\text { activity } \\
\text { primary general } \\
\text { education } \\
\text { programmes } \\
\text { implementation }\end{array}$ & $\begin{array}{c}\text { Proportion of } \\
\mathrm{JF}, \%\end{array}$ \\
\hline $\begin{array}{l}\text { Professional } \\
\text { standard }\end{array}$ & 10 & 12 & 11 & 7 & $40 / 100 \%$ \\
\hline BPEP & 10 & 12 & 6 & 5 & $33 / 82,5 \%$ \\
\hline
\end{tabular}

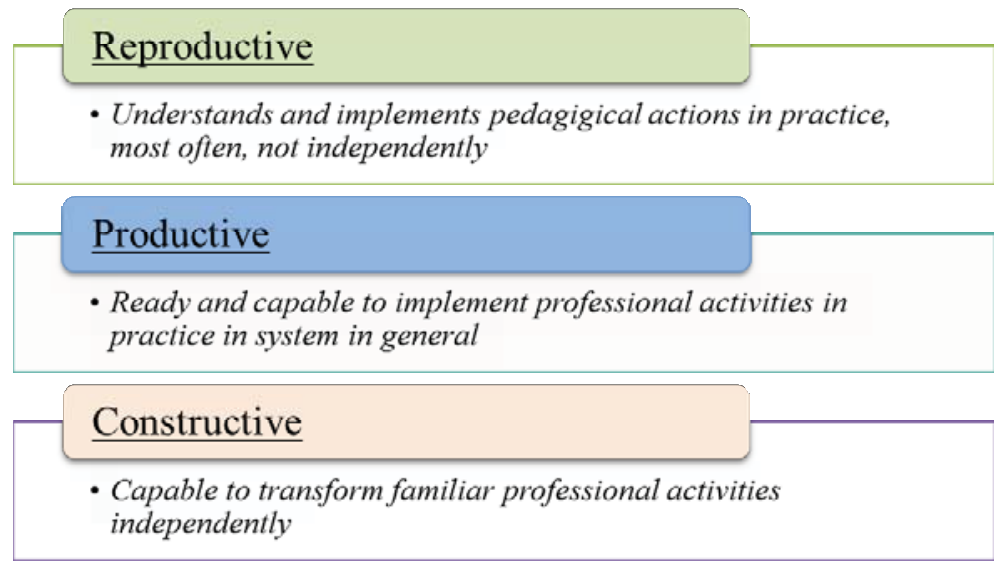

Fig. 1. Level model of educational results

represented in the measured products of his/ her activity. The model assumes the use of the three levels of educational results formation: reproductive, productive and constructive (Fig. 1).

The reproductive level means that student understands the principle of the carried out pedagogical activity in practice in the context of its individual components.

In turn, the productive level demonstrates students' understanding of the principle of pedagogical activity organization in practice as a whole, as well as in the system of all its interconnected components. The constructive level characterizes transformation of the familiar to students holistic principle of pedagogical activity organization into a new (author's) principle and its subsequent integration with the other approaches of pedagogical activity organization.

In the process of training, at the entrance and at the end of the module and exit from BPEP, educational results are formed at one of the three levels and are subjected to independent professional assessment (Fig. 2).

Quality assessment of bachelor's programmes mastering by students includes current monitoring of students' progress, interim students' assessment and final attestation (which may include defense of personal electronic portfolios that were generated during the whole course of study).

Interim attestation - assessment of students' academic achievements in the discipline or modules under study. It is held at the end of the calendar module or at the end of the discipline 


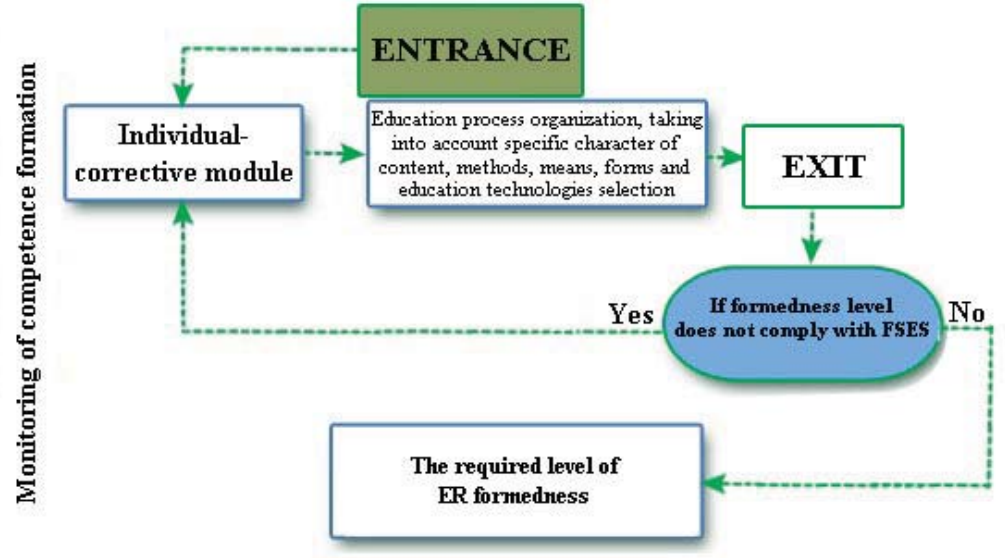

Fig. 2 Monitoring of the level of educational results formation

study in the form of professional examination or competence-based tests.

Current attestation - assessment of students' academic achievements in different types of learning activities in the course of the discipline study.

Final attestation - comprehensive control of student's educational achievements and professional functions for the entire period of study; held in the form of complex examination and practice-oriented project defense (graduation thesis, graduation project, final examination and electronic portfolio defense).

Professional teacher's standards and the standard of the future teachers training impose new demands for educational results and the new philosophy of assessment. A shift of emphasis from the formal assessment of educational results to the expert assessment, self-assessment and peer assessment is taking place. An effective technology, used in the system of authentic assessment is electronic portfolio, which is widely used in international education systems and is gaining popularity in the Russian practice.

Thus, assessment for education is more than just grading. It is teacher's involvement in the planning of the next phase of training and a possibility for a student to see and understand his/her problem areas in education and plan the next stage of education.

E-portfolio technology, under current conditions, focuses on students' personality and on the importance of educational results for the student.

One of the necessary conditions to improve the quality of training is to increase students' initiative and responsibility for the results of their training, personal and professional development. In the conceptual framework it is implemented through: training contract, electronic diary of practical trainings, development and modification of individual educational route and open representation of educational and scientific achievements in students' electronic portfolio (e-portfolio). Due to such an organization of educational process, in the course of the experiment, student's educational results have to change. Assessment system is of particular importance for student's assessment, because it becomes open, integrated and comprehensible.

In the new model of the primary school teachers' training not only the content, but also the methods of teaching are changing. E-learning and interactive digital educational resources are becoming more and more important; facilities for educational content MOODLE management are 
used. Electronic portfolio technology is widely used in the information and educational space, not only for the authentic students' assessment, but also as a tool of reflection, as a technology of personal and professional development that allows students to collect artifacts both for presentation on the competency tests, and to the potential employers. Practice diary in e-portfolio format and competency testing at the Quest act as cultural means of incorporated and meaningful observation organization and trial-project students' activity in a situation of immersion into different types of educational activities.

Professional teacher's standards and the standard of the future teachers training impose new demands for educational results and the new philosophy of assessment. A shift of emphasis from the formal assessment of educational results to the expert assessment, self-assessment and peer assessment is taking place. (Fig. 3).

An effective technology, used in the system of authentic assessment, is electronic portfolio, which is widely used in international education system (Margolis \& Rubtsov, 2010b; Rubtsov, 2008).

AccordingtoH.Barrett,educationalparadigm is changing from the "Assessing education" to
“Assessing for education". George Roberts (2006) identifies the following significant features of the assessment system for education: understanding the objectives and the results of assessment by student, external assessment and self-assessment inclusion and connection of assessment with the next "stages" of education (Elementary..., 2007; Roberts, 2006). Thus, assessment for education is more than just grading. It is teacher's involvement in the planning of the next phase of training and a possibility for a student to see and understand his/her problem areas in education (Barrett, 2007; Professional..., 2012).

Helen Barrett identifies a number of important factors that have to contribute to the development of education assessment system quality: development of cognitive theories and understanding the subject of assessment, development of the technology of results measurement and advanced methods of complex education results interization. When using e-portfolio technologies under current condition we, after many modern European and American researchers, are focusing on personal results of student's training (Table 2) and on the importance of the assessment system for the student (Zimniaia, 2004).

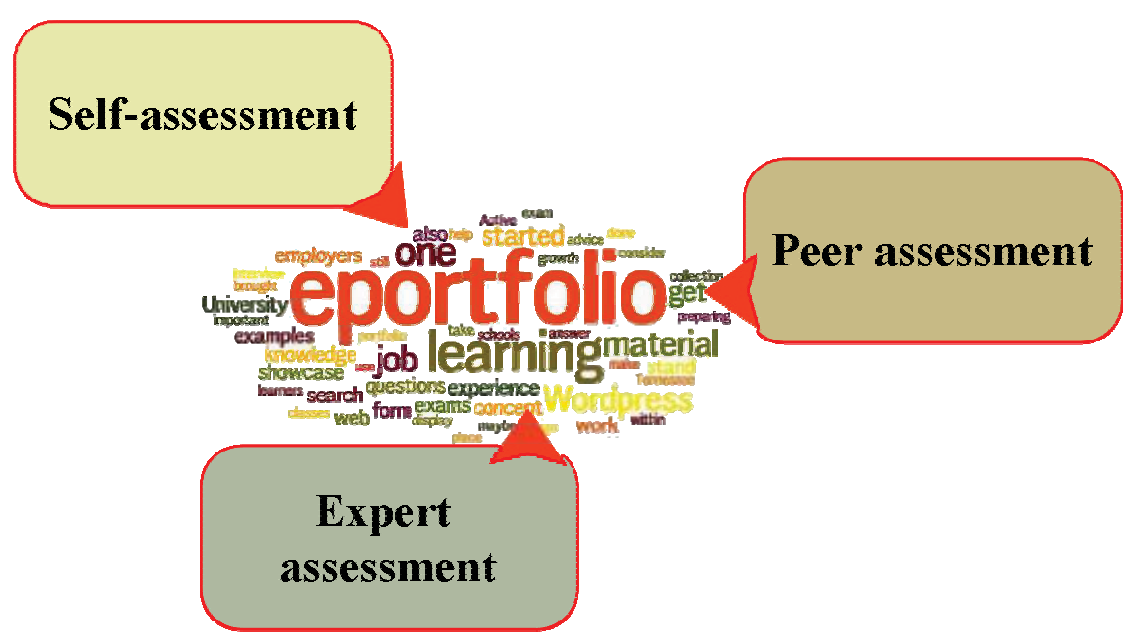

Fig. 3. The system of students' educational results assessment through e-portfolio in the new model of education 
Table 2. E-portfolio in the system of training and assessment

\begin{tabular}{|l|}
\hline E-portfolio method in the education system, focused on student's development \\
\hline The purpose of the portfolio is coordinated with the student \\
\hline Artifacts are selected by students to describe the history of their own educational progress \\
\hline The portfolio is developed throughout the training period \\
\hline $\begin{array}{l}\text { The portfolio and artifacts are updated by the student and used to provide feedback to improve educational } \\
\text { results }\end{array}$ \\
\hline The portfolio is corrected by the student and discussed with the tutor, consultant or lecturer \\
\hline The portfolio technology is used to make important decisions of the educational process reconsideration \\
\hline Induces inner motivation - involves the student \\
\hline $\begin{array}{l}\text { The target audience of the portfolio is: the student, family, friends, lecturers, expert community and potential } \\
\text { employers - a greater choice of the student }\end{array}$ \\
\hline
\end{tabular}

Thus, the student, working on e-portfolio materials, which in the future will allow him/her to demonstrate their achievements, "creates the story of his/her training and development" in the virtual space.
The portfolio indeed becomes an instrument of authentic assessment, if it includes the methods of student's skills fixation in the model case situations and real situations of professional activity.

\section{References}

Barrett, H. (2007). Researching Electronic Portfolios and Learner Engagement. The REFLECT Initiative. Journal of Adolescent and Adult Literacy, 50(6), 436-449.

Bolotov, V.A. Programma modernizatsii pedagogicheskogo obrazovaniia 2014-2017 [The Programme of Pedagogical Education Modernization 2014-2017] [Digital resource] // Portal for Support of the Projects of Pedagogical Education Modernization. Available at: http:// pedagogicheskoeobrazovanie.rf/ documents/show/14 (accessed date 15.09.2014).

Elementary Education Standards and Supporting Explanation. International Association for Childhood Education, 2007.

Federal'nyi obrazovatel'nyi standart obshchego (nachal'nogo) obrazovaniia [Federal Educational Standard of General (Primary) Education]. MES RF, 2009.

Guruzhapov, V.A., Margolis, A.A. (2014) Proektirovanie modeli praktiko-orientirovannoi podgotovki pedagogicheskih kadrov po programmam bakalavriata po napravleniiu podgotovki "Psikhologo-pedagogicheskoe obrazovanie" (Uchitel' nachal'nykh klassov) na osnove setevogo vzaimodeistviia obrazavatel'nykh organizatsii realizuiushchikh programmy vysshego obrazovaniia i nachal'nogo obshchego obrazovaniia [Designing the Model of Practice-Oriented Pedagogical Staff Training on Bachelor's Degree Programme on Specialty "Pedagogical and Psychological Education" (Primary School Teacher) Based on the Networking of Educational Organization, Implementing Higher Education and Primary General Education Programmes]. Psychological Science and Education, 19(3), 143-159.

Korshunova, V.V., Smolyaninova, O.G., Yudina Yu.G. (2014). Novaia model' podgotovki uchitelei nachal'nykh klassov: etap aprobatsii - sibirskii variant [New Model of Primary School Teachers 
Training: Testing Stage - Siberian Version]. Science and School, 6, 34-48, available at: http://elibrary. ru/item.asp?id=22703542.

Margolis, A.A., Rubtsov, V.V. (2010). Psikhologopedagogicheskaia podgotovka uchitelei dlia novoi shkoly [Pedagogical and Psychological Training for the New School Teachers]. Education Policy, 5-6 (43-44).

Margolis, A.A., Rubtsov, V.V. (2010). Uchitel' dlia novoi shkoly: modernizatsiia pedagogicheskogo obrazovaniia v Rossii [Teacher for New School: Modernization of Pedagogical Education in Russia]. Education Policy, 4.

Professional'nyi standart pedagoga [Professional Teacher's Standard]. MES RF. Moscow, 2012.

Roberts, G. (2006). Wider Opportunities for Reflection, Learning and Development. JISCDistributed E-Learning, Available at: http://www.jisc.ac.uk/media/documents/programmes/ distributed_elearning/myworld_petal2_draftfinal.doc.

Rubtsov, V.V. Sotsial'nogeneticheskaia psikhologiia razvivaiushchego obrazovaniia [Social and Genetic Psychology of Developmental Education]. Moscow, 2008.

Zimniaia I.A. Kliuchevye kompetentnosti kak rezultativno-wtktdfz osnova kompetentnostnogo podkhoda v obrazovanii [Key Competences as Resultative and Target Basis of Competence-Based Approach in Education]. Author Version. Moscow, Research Centre of Specialists Training Quality Problems, 2004, 40 p.

\title{
Оценивание образовательных результатов будущих учителей начальной школы
}

\author{
О.Г. Смолянинова, В.В. Коршунова \\ Сибирский федеральный университет \\ Россия, 660041, Красноярск, пр. Свободный, 79
}

\begin{abstract}
В статье обсуждаются вопросы изменения программ подготовки и оценки образовательных результатов будущих учителей начальных классов в контексте модернизачии педагогического образования, связанные с требованиями профессионального стандарта педагога. В иелях усиления практической направленности подготовки будущих учителей начальных классов авторы предлагают технологию оценивания образовательных результатов средствами электронного портфолио в условиях сетевого взаимодействия основных систем, включенных в процесс подготовки: системы СПО и системь ВО и работодателей. Анализируя профессиональный стандарт педагога, были выделены трудовые действия для каждой из трудовых функиий (обучение, воспитание, развитие), определена дельта на уровнях высшего образования (бакалавриата) и предложены уровни оценки образовательных результатов.
\end{abstract}

Ключевые слова: интеграчия, непрерывное педагогическое образование, практическая направленность подготовки, технология оценивания, образовательные результаты, порфтолио.

Работа была выполнена в рамках исполнения Государственного контракта Министерства образования и науки РФ № 05.043.12.0031.

Научная специальность: 13.00.00 - педагогические науки, 19.00.00 - психологические науки. 